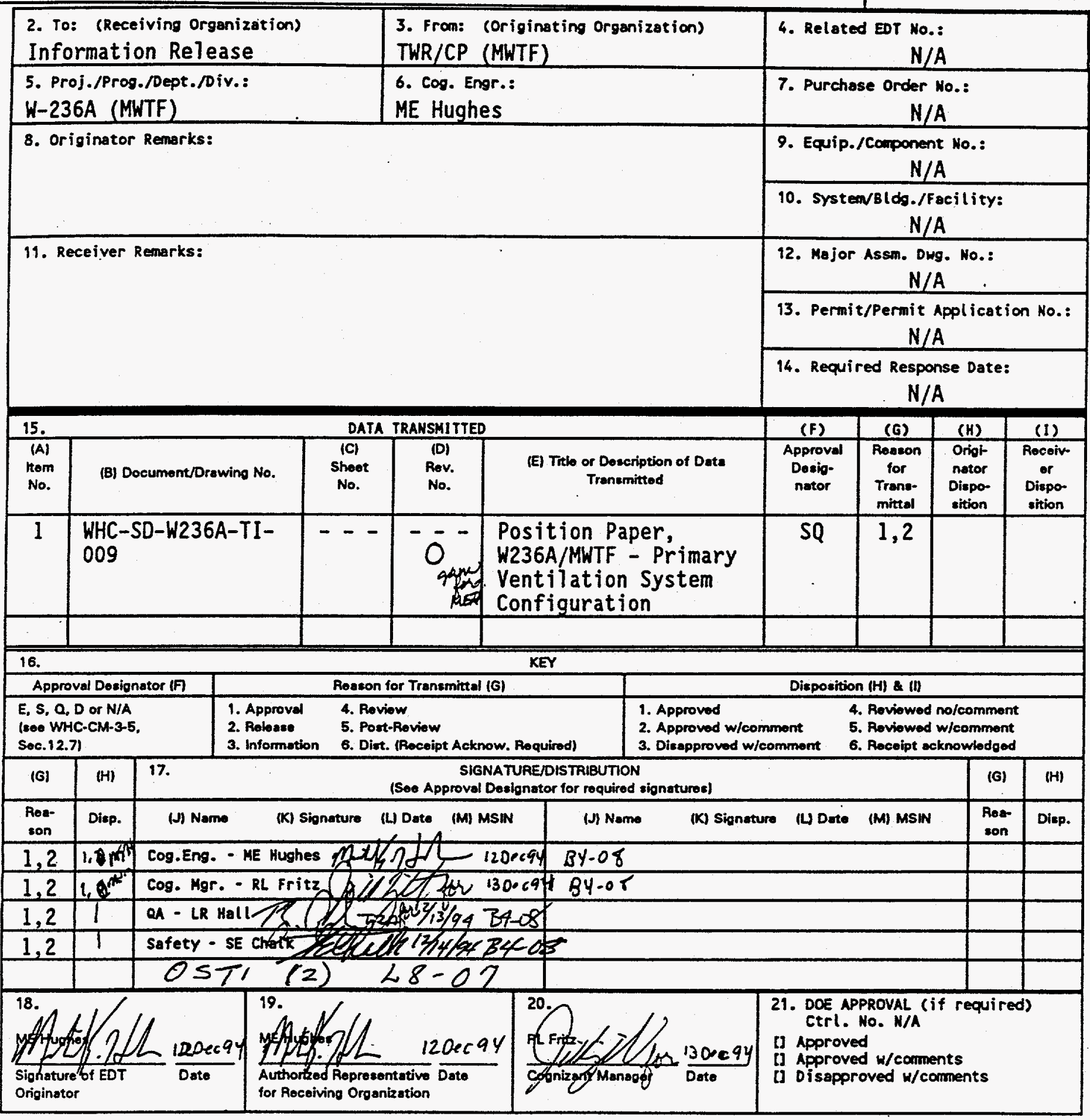

BO-7400-172-2 (04/94) GEF097 


\section{DISCLAIMER}

Portions of this document may be illegible in electronic image products. Images are produced from the best available original document. 


\section{RELEASE AUTHORIZATION}

\section{Document} Number:

Document

Title:
WHC-SD-W236A-TI-009 Rev. 0

Position Paper - Primary Ventilation System

Configuration

Release Date: January 4, 1995

\section{This document was reviewed following the procedures described in WHC-CM-3-4 and is:}

\section{APPROVED FOR PUBLIC RELEASE}

\section{WHC Information Release Administration Specialist:}

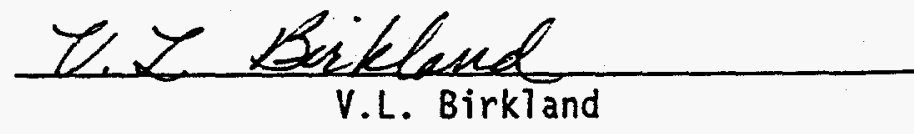

January 4, 1995

\section{V.L. Birkland}

TRADEMARK D1SCLAIMER. Reference herein to any specific comercial product, process, or service by trade name, trademark, manufacturer, or otherwise, does not necessarily constitute or imply its endorsement, recomendation, or favoring by the United states Government or any agency thereof or its contractors or subcontractors.

This report has been reproduced from the best available copy. Available in paper copy and microfiche. Printed in the United States of America. Available to the U.S. Department of Energy and its contractors from:

$$
\begin{aligned}
& \text { U.S. Department of Energy } \\
& \text { Office of Scientific and Technical Information (OSTI) } \\
& \text { P.O. Box } 62 \\
& \text { Oak Ridge, TN } 37831 \\
& \text { Telephone: (615) } 576-8401
\end{aligned}
$$




\section{2. ritle \\ Position Paper - Primary Ventilation System Configuration}

\section{Key Words}

TANKS, MWTF, POSITION PAPER, VENTILATION SYSTEM

\section{Number}

WHC-SD-W236A-TI-009
4. Rev No.

0
6. Nuthor

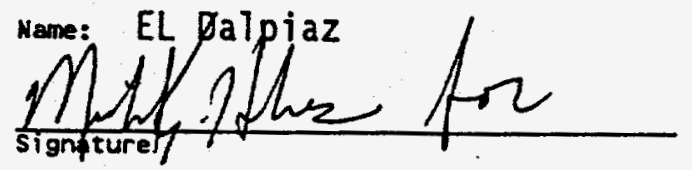

Organization/Charge Code

\section{Abstract}

Position Paper to develop and document a position on the configuration of the primary ventilation system.

\section{DISCLAIMER}

This report was prepared as an account of work sponsored by an agency of the United States Government. Neither the United States Government nor any agency thereof, nor any of their employees, makes any warranty, express or implied, or assumes any legal liability or responsibility for the accuracy, completeness, or usefulness of any information, apparatus, product, or process disclosed, or represents that its use would not infringe privately owned rights. Reference herein to any specific commercial product, process, or service by trade name, trademark, manufacturer, or otherwise does not necessarily constitute or imply its endorsement, recommendation, or favoring by the United States Government or any agency thereof. The views and opinions of authors expressed herein do not necessarily state or reflect those of the United States Government or any agency thereof.
8.

RELEASE STAMP

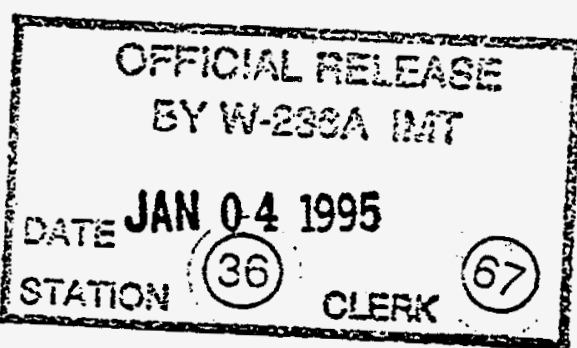




\title{
Position Paper \\ Primary Ventilation System Configuration
}

\author{
Project W-236A \\ Multi-Function Waste Tank Facility
}

prepared by ICF Kaiser Hanford Company

for Westinghouse Hanford Company

June 1994

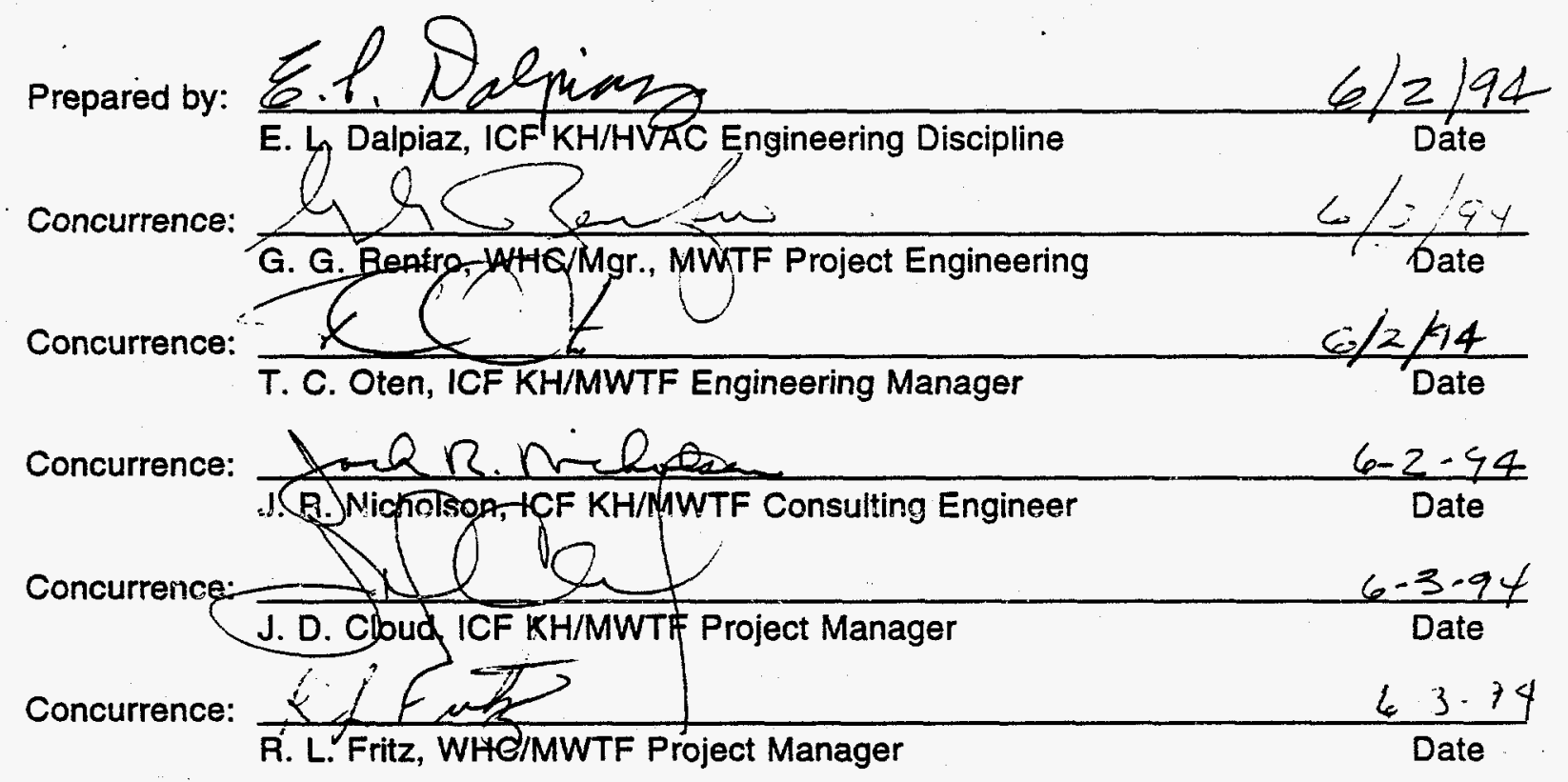


WHC-SD-W236A-TI-009

Rev.0

W236A 71PR5

\section{Contents}

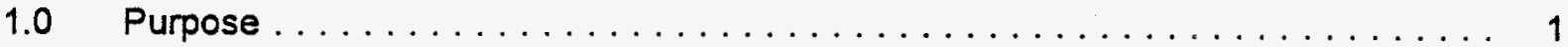

2.0 Background $\ldots \ldots \ldots \ldots \ldots \ldots \ldots \ldots \ldots \ldots \ldots \ldots \ldots \ldots \ldots \ldots \ldots$

3.0 Discussion . . . . . . . . . . . . . . . . . . . . . . 2

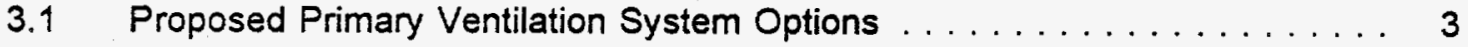

3.2 Comparison of Options . . . . . . . . . . . . . . . . . . 5

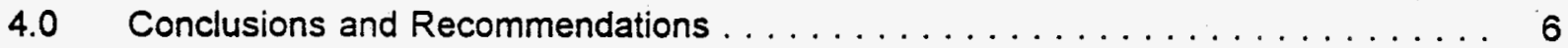

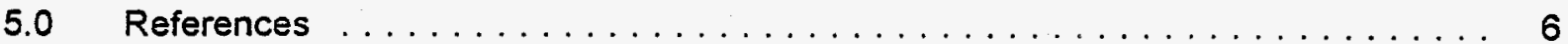

\section{Attachments}

Attachment A

Diagrams

Attachment $B$

Breakdown of Estimated Savings 


\title{
Position Paper \\ Primary Ventilation System Configuration
}

\author{
Project W-236A \\ Multi-Function Waste Tank Facility
}

\subsection{Purpose}

The purpose of this paper is to develop and document a position on the configuration of the primary ventilation system. This configuration will be used on the waste storage tanks currently being designed for the Multi-Function Waste Tank Facility (MWTF), Project W-236A.

\subsection{Background}

The Title I design of the primary tank heat removal system consists of two systems:

- A primary tank vapor space ventilation system

- An annulus ventilation system

The primary ventilation system provides a single treatment train and exhaust fan for each waste storage tank. The ventilation systems from each of two tanks are grouped with an additional treatment train and exhaust fan that function as backup to either of the two systems. . Diagrams of these systems are presented in Attachment A. The annulus ventilation system has a treatment train and a backup that are common to all waste storage tanks. 


\subsection{Discussion}

During the Advanced Conceptual Design phase of this project, a report was prepared (ref 1 ) that addressed proposals from a functional analysis review. This review examined technical, cost, and schedule baselines established for the MWTF. One of the proposals from this review was to revise the functional design criteria to permit optimization of the waste storage tank ventilation systems (both primary and annulus) by combining independent cleanup trains into a centralized system. The annulus system was centralized as a result of this proposal. However, the primary system was not combined into a centralized system because of operational and safety issues, including incompatible waste streams, system effectiveness demonstration, ammonium nitrate formation, and operational diversity and flexibility.

Based on recommendations from a materials evaluation report (ref 2), a revision to the Functional Design Criteria for this project is in process that will change the materials of the primary tank to carbon steel. As a result of this change in material and corresponding operational restrictions to limit the tanks to receiving and storing only high-alkaline waste, the primary exhaust from the tanks could be combined into a single header prior to, or at some point during, treatment (ref 3). The change to the more restrictive operation limits (ref 4 ) resolves the issues of incompatible waste streams, system effectiveness demonstration, and ammonium nitrate formation noted above.

The management of condensate and high-efficiency metal fiber (HEMF) filter backwash becomes a concern if the primary exhaust streams are combined prior to the condensers, high-efficiency mist eliminator (HEME) filter, or HEMF filter. To direct the condensate and HEMF backwash to a single tank would probably require waste chemistry adjustment capabilities for the tanks. It would also require that operations personnel monitor and take action to maintain the tank chemistry within operating specifications. Options for combining the primary exhaust systems were presented and evaluated in a working meeting (ref 5). The requirement for management of the 
condensate was evaluated during this meeting, and it was determined that the condensate should be returned to the tank from which it came. The working meeting evaluated the options to determine if they meet operational diversity and flexibility requirements. It was concluded that these requirements were met, thus resolving the issue in the Functional Analysis Review report.

\subsection{Proposed Primary Ventilation System Options}

The following options for combining the primary ventilation systems into centralized systems were considered. Diagrams of the options are presented in Attachment A.

Option A: This option basically maintains the Title I system configuration, except it eliminates four 150-foot-tall primary exhaust stacks by combining the exhaust from the primary systems at the base of the main exhaust stack. Since the principle of combining exhaust stacks is an integral part of each of the other options, this option will not be considered further.

Option B: This option combines the primary ventilation system from two tanks into a single cleanup train with a backup. The features of this option are the elimination of two complete treatment trains in the 200-East facility and the elimination of one treatment train in the 200-West facility. It also eliminates two monitoring stations in 200 East and one station in 200 West. The valve manifolds are located in cells requiring remote replacement (jumpers with remote flanges). The condensate and filter backwash removed from the primary airstream cannot be returned to the tank from which it came.

Option BB: This option is similar to option B for the 200 -East facility. It combines all four tanks after the cell treatment equipment into a single high-efficiency particulate air/high-efficiency gas adsorber (HEPA/HEGA) fan system with a backup. This option has the same features as option $B$ with an added feature of eliminating another stack monitor system and two HEPA/HEGA fañ systems. 
Option DF: This option maintains the cell treatment arrangement as proposed in Title $I$ and combines all tanks downstream of the cell treatment equipment into a single HEPA/HEGA fan system with a backup. The features of this option are that the control valves are placed downstream of the cell treatment train in a contact maintenance area; four HEPA/HEGA fan systems are eliminated in the 200-East facility, and one system is eliminated in the 200 -West facility. Option DF also eliminates three monitoring systems in 200 East and one monitoring system in 200 West. This arrangement would provide different-sized equipment in the HEPA/HEGA fan systems from 200 East to 200 West, which will reduce the opportunities for interchanging spare parts between the sites.

Option BF: This option is similar to option DF for the 200-East facility except that it combines two tanks into a common HEPA/HEGA fan system with a backup. The features of this option are that there would be similar-sized equipment in the HEPA/HEGA fan systems of 200 East and 200 West. This would minimize spare parts, operating procedures, and maintenance procedures. It also eliminates two monitor systems and three HEPA/HEGA fan systems.

Option C: This option combines all primary exhaust from the individual tanks into a single treatment train with a backup. The features of this option are elimination of four treatment trains in the 200-East facility and one treatment train in the 200-West facility. It could eliminate four process cells in the 200-East facility and one cell in the 200-West facility. Three monitoring systems in the 200-East facility and one system in the 200-West facility are also eliminated. The control valve manifolds, which are located in pits in the tank farm or in cells of the Support Facility, require remote replacement (jumpers with remote flanges). The condensate removed from the primary airstream and filter backwash cannot be returned to the tank from which it came. This option would have the greatest impact on engineering since the Support Facility in both 200 East and 200 West would have to be reworked. 


\subsection{Comparison of Options}

Option B, BB, and C are not preferred options because of the disadvantage of not being able to return condensate to the tank from which it carne. They also have the added disadvantage of having control valve manifolds located in a cell or pit, which would require remote replacement.

Options DF and BF have a separate cell treatment train for each tank that allows condensate from the primary tank airstream to drain back to the tank from which it came. The control valve manifolds in these options are located in a contact maintenance area. These features make options DF and BF preferred options.

A disadvantage of option DF is that the 200-East system would not be similar to the configuration in 200 West as it is in option BF (two waste storage tanks connected to a common exhaust system). Tank farm operating personnel are expected to work at. either tank farm, and option BF provides similar operating systems in both tank farms. However, the method of controlling the pressure in each tank is the same for both options, and the difference in systems operation is not significant.

Another disadvantage of option DF is that the 200-East system fan is larger than the 200 -West system fan (2000 cfm vs. $1000 \mathrm{cfm}$ ), which will require the procurement and storage of two different-sized fans for spares. The disadvantage of two different fans, however, is more than offset by the difference in cost of the two options. The estimated cost savings for each option is shown in Table 1. If the cost of an additional spare fan for option DF was deducted from its estimated savings, this option would still exceed the savings of option BF by approximately $\$ 1,000,000$. See Attachment $B$ for the breakdown of estimated savings. 
Table 1

Cost Impacts

\begin{tabular}{|c|c|c|}
\hline \multicolumn{2}{|c|}{ Options } & \multirow{2}{*}{$\begin{array}{c}\text { Estimated Cost } \\
\text { Savings (TPC) }\end{array}$} \\
\hline $200 E$ & $200 W$ & $\$ 5,721,300$ \\
\hline DF & DF & $\$ 4,513,200$ \\
\hline BF & BF & \\
\hline
\end{tabular}

The primary advantages of option DF when compared to option BF are increased cost savings; less equipment to procure, install, and test; and less equipment to operate and maintain over the life of the facility.

\subsection{Conclusions and Recommendations}

Based on the preceding discussions and cost impacts, ICF KH concludes that option DF be incorporated into the design of the 200-East and 200-West primary ventilation system for MWTF.

\subsection{References}

1. Report, Functional Analysis Review Proposal Recommendations, Document No. W236A-01, prepared by ICF Kaiser Hanford Company, January 1993.

2. Report, Multi-Function Waste Tank Facility Materials Evaluation Report, Document No. WHC-SD-W236A-TRP-003, prepared by Westinghouse Hanford Company.

3. DSI, R. F. Meisinger to T. C. Oten, Possible Simplification of the W-236A Tank Ventilation Systems, March 9, 1994. 
WHC-SD-W236A-TI-009

Rev. 0

-4236A I1 PPS

4. Operating Specifications for the 241-AN, AP, AW, AY, AZ, and SY Tank Farms, OSD-T-151-00007.

5. W-236A Engineering Working Meeting Minutes, April 12, 1994. 
WHC-SD-W236A-TI-009

Rev.0

Attachment A

Diagrams

Position Paper

A -1

Primary Ventilation System Configuration 
WHC-SD-W236A-TI-009

Rev. 0
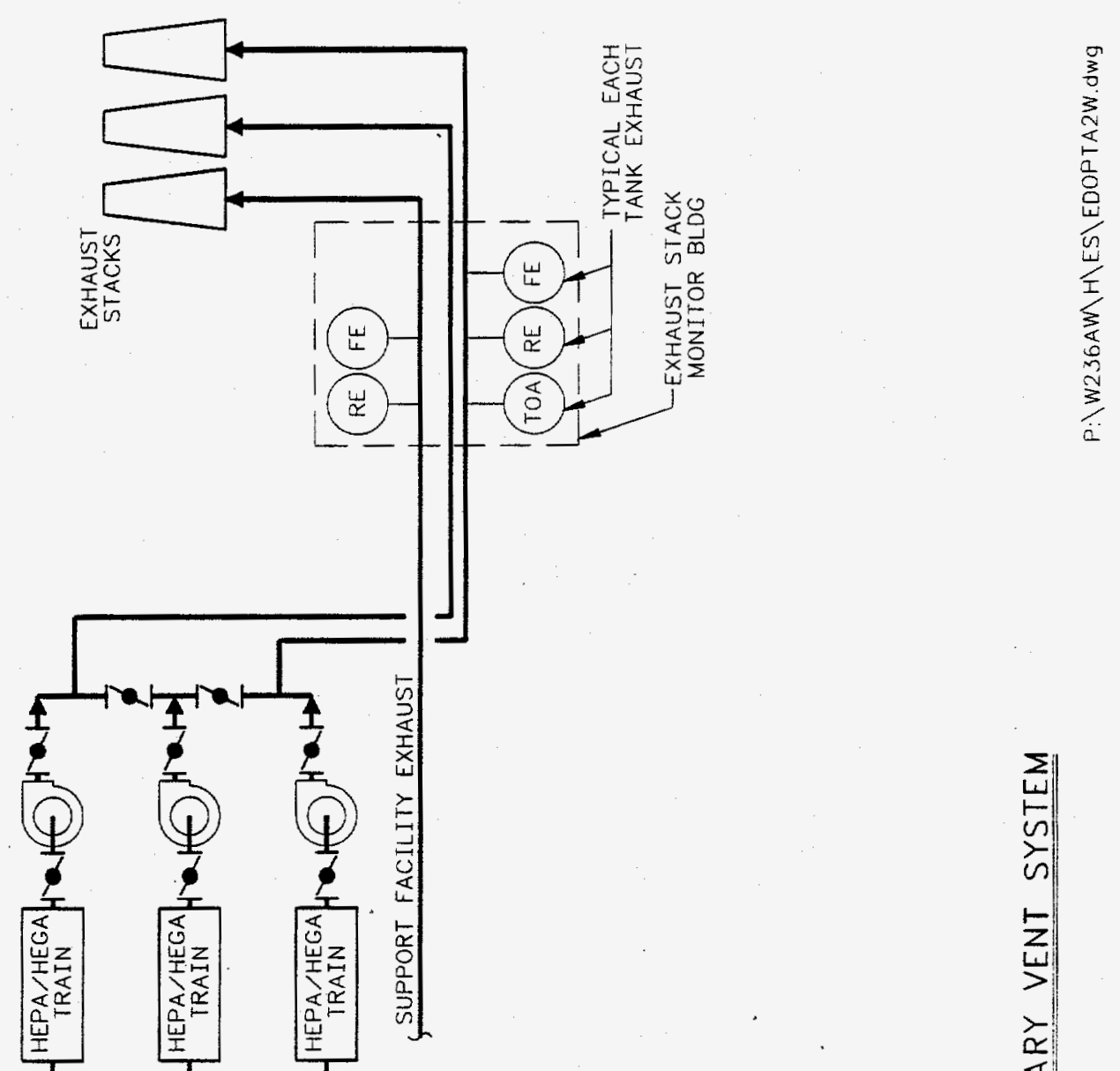

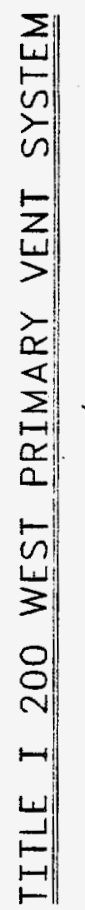
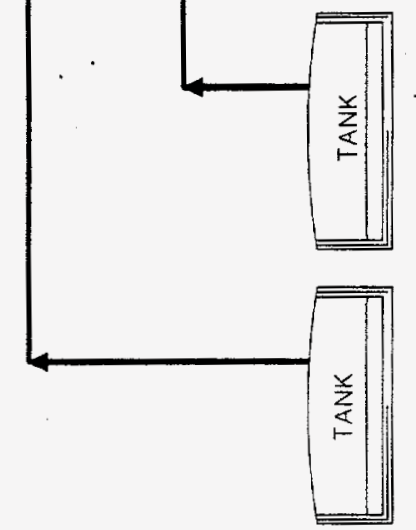

A - 2 
WHC-Sd-W236A-TI-009

Rev. 0
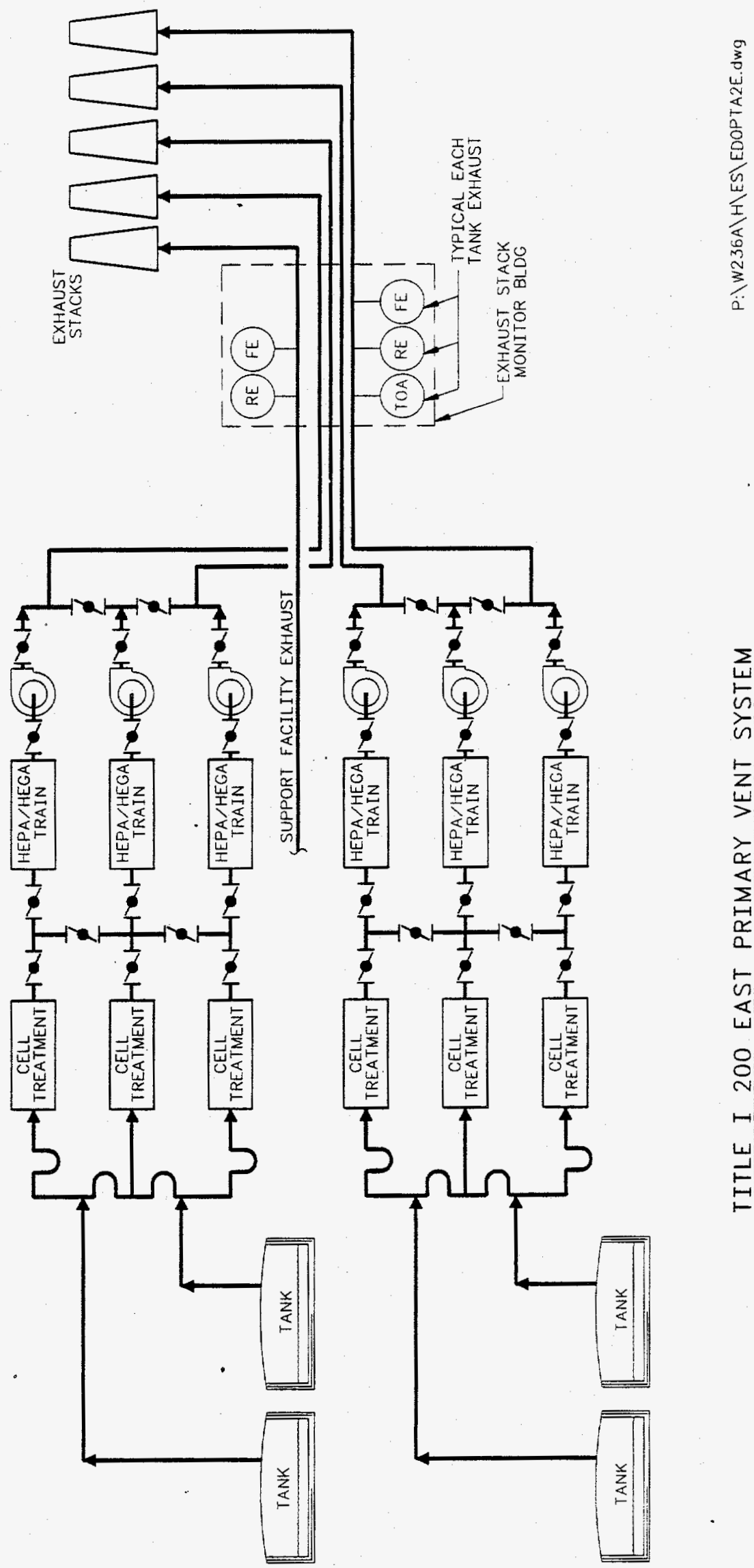

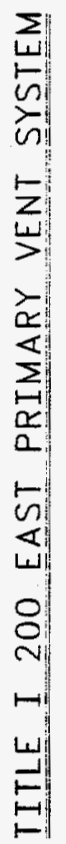

A -3 


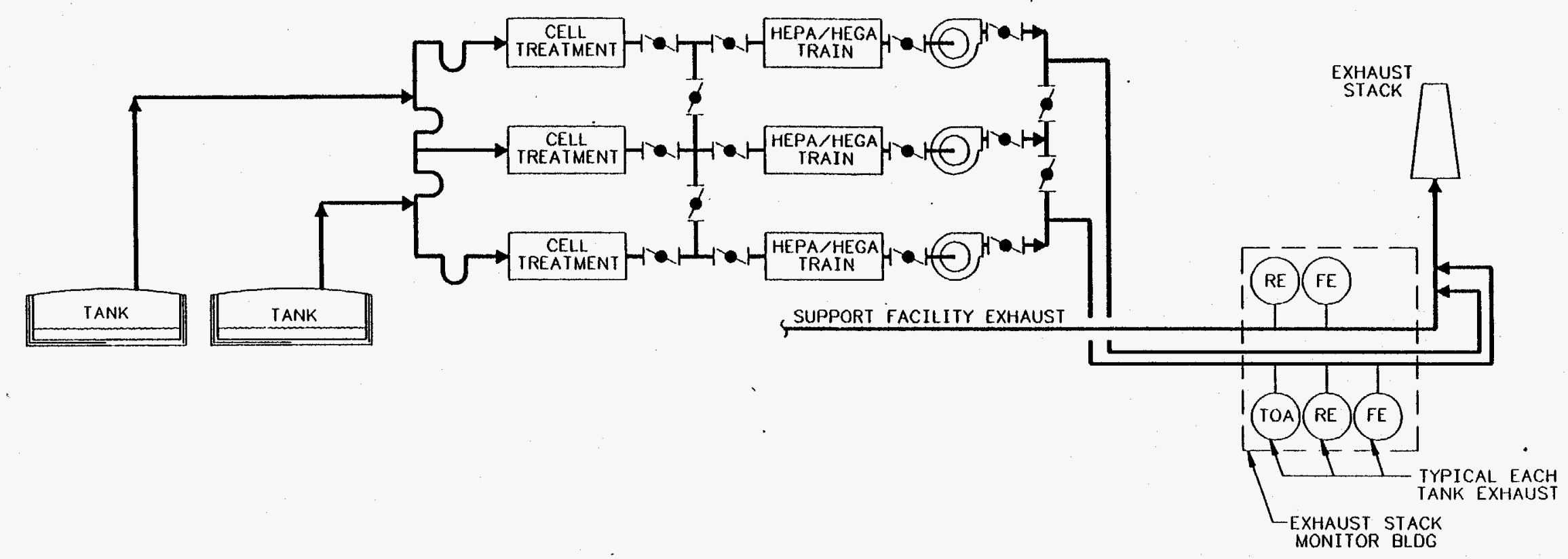

OPIION "A"

SAME PRIMARY AND SAMPLING SYSTEMS AS TITLE I, ELIMINATES (2) PRIMARY STACKS BY COMBININC ALL EXHAUS 


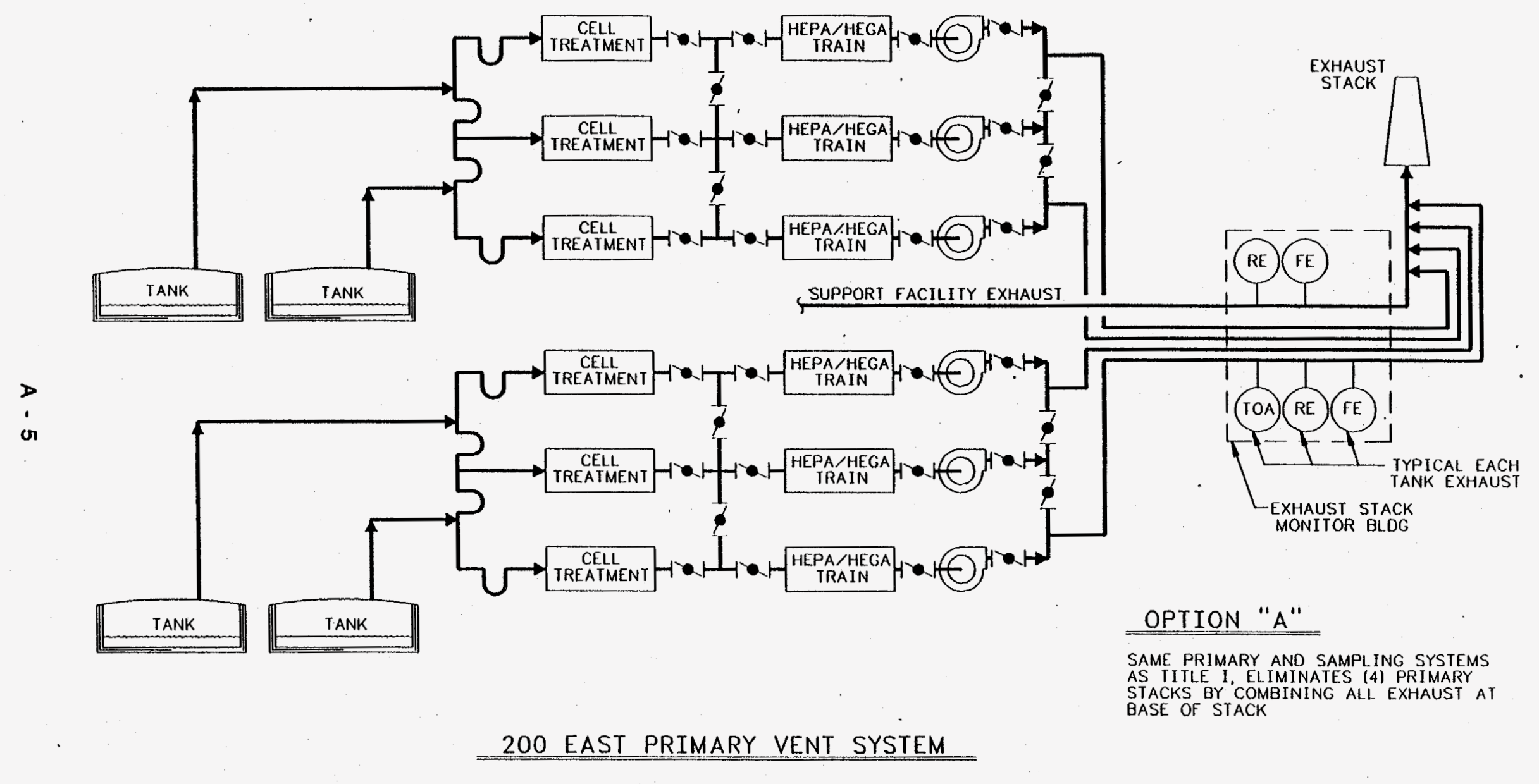




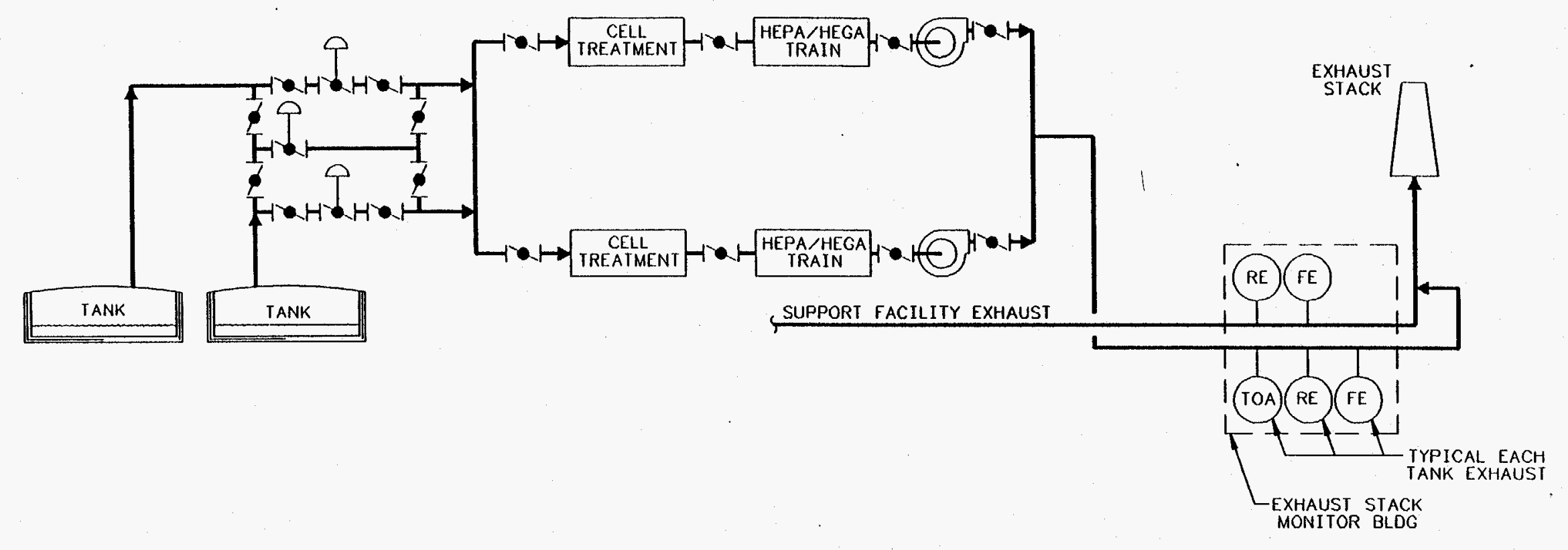

OPTION "B"

- COMBINES PRIMARY SYSTEM FROM TWO TANKS INTO A SINGLE TREATMENT TRAIN WITH BACKUP ELIMINATES (1) COMPLETE TREATMENT TRAIN 200 WEST PRIMARY VENT SYSTEM - VALVE MANIFOLD IS LOCATED IN CELL VACATED 


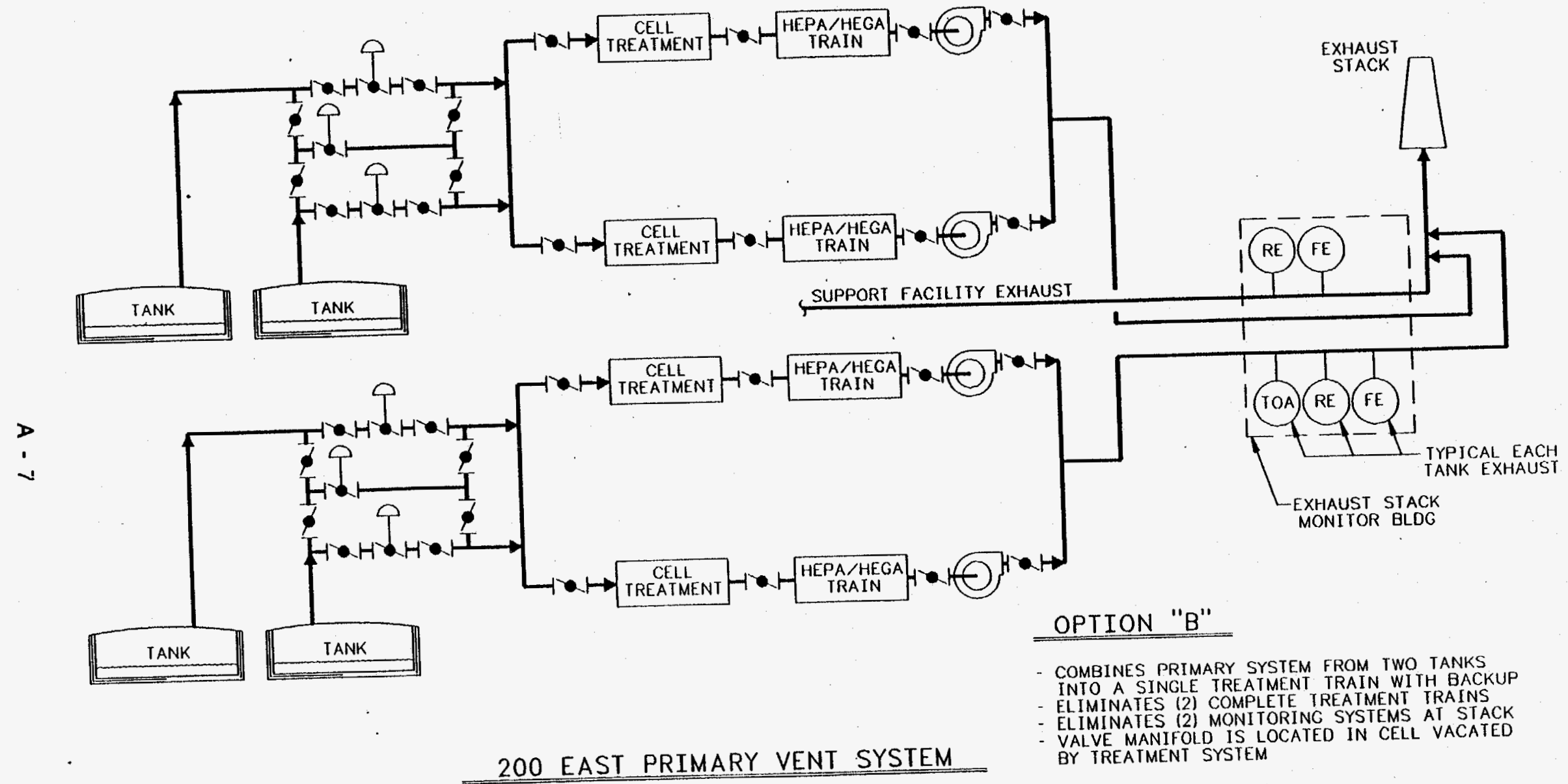




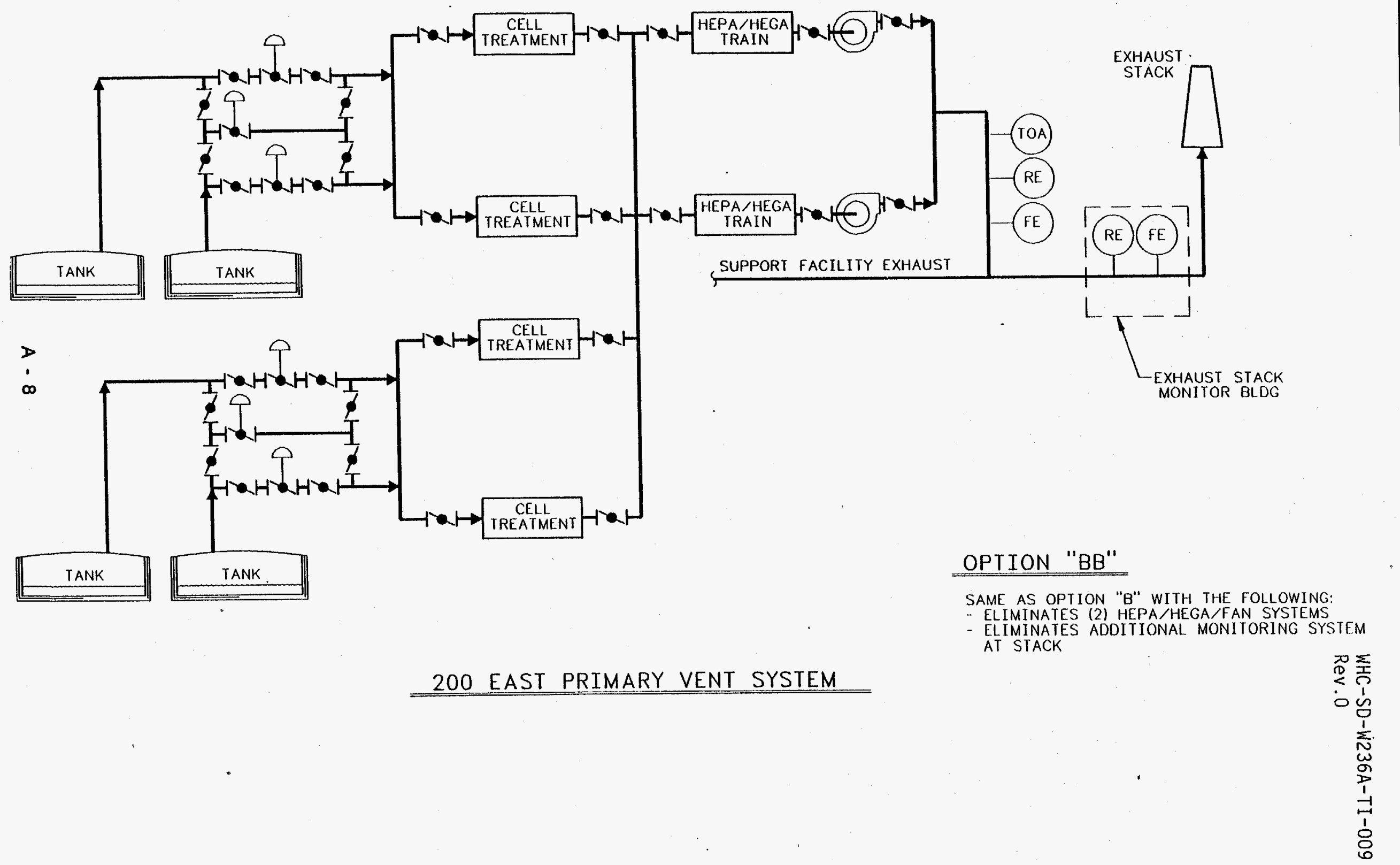




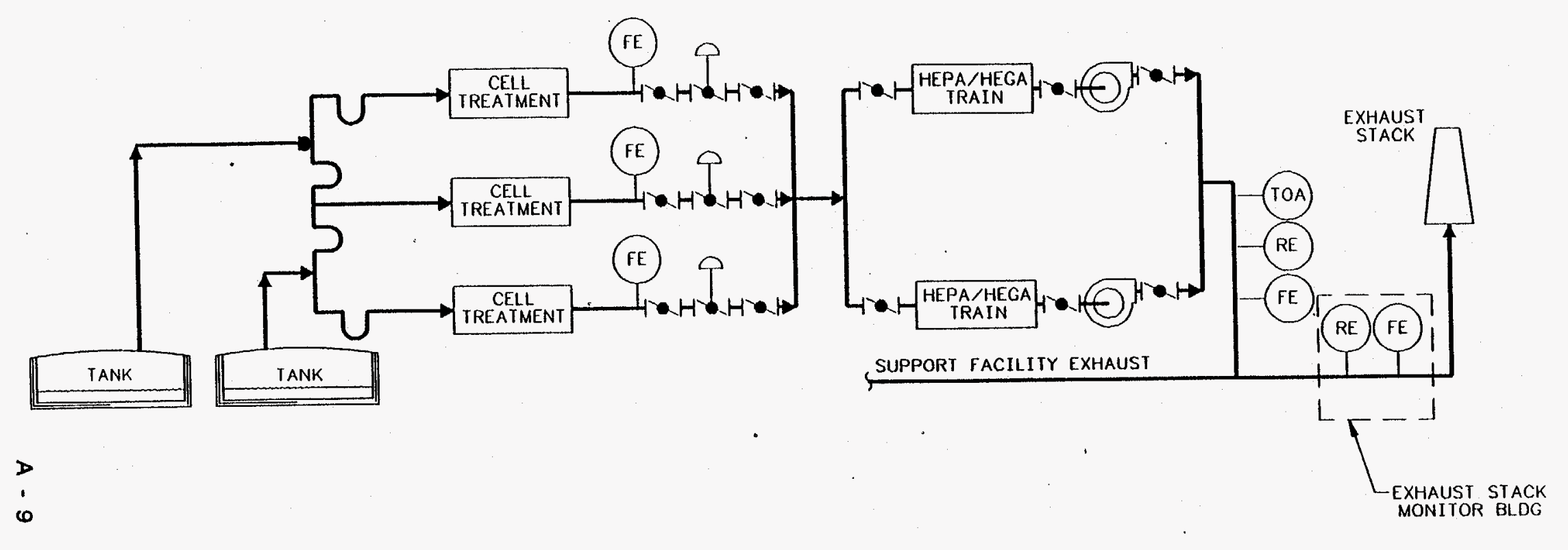

200 WEST PRIMARY VENT SYSTEM

OPTION "DF"

SAME AS OPTION "BB" WITH THE FOLLOWING:

- ELIMINATES VALVES IN CELLS, PLACES VALVES

IN CONTACT MAINTENANCE AREA 


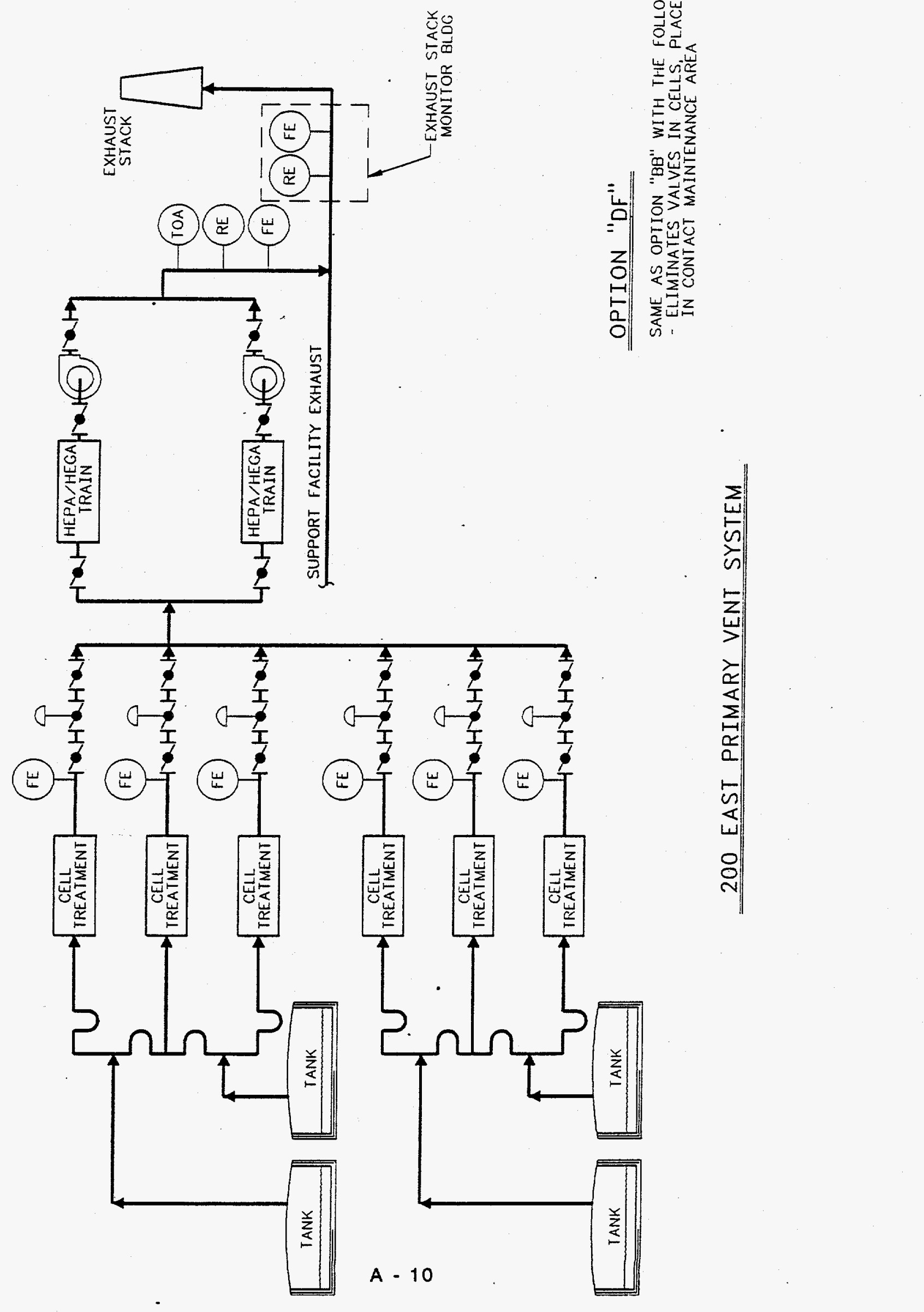


FE
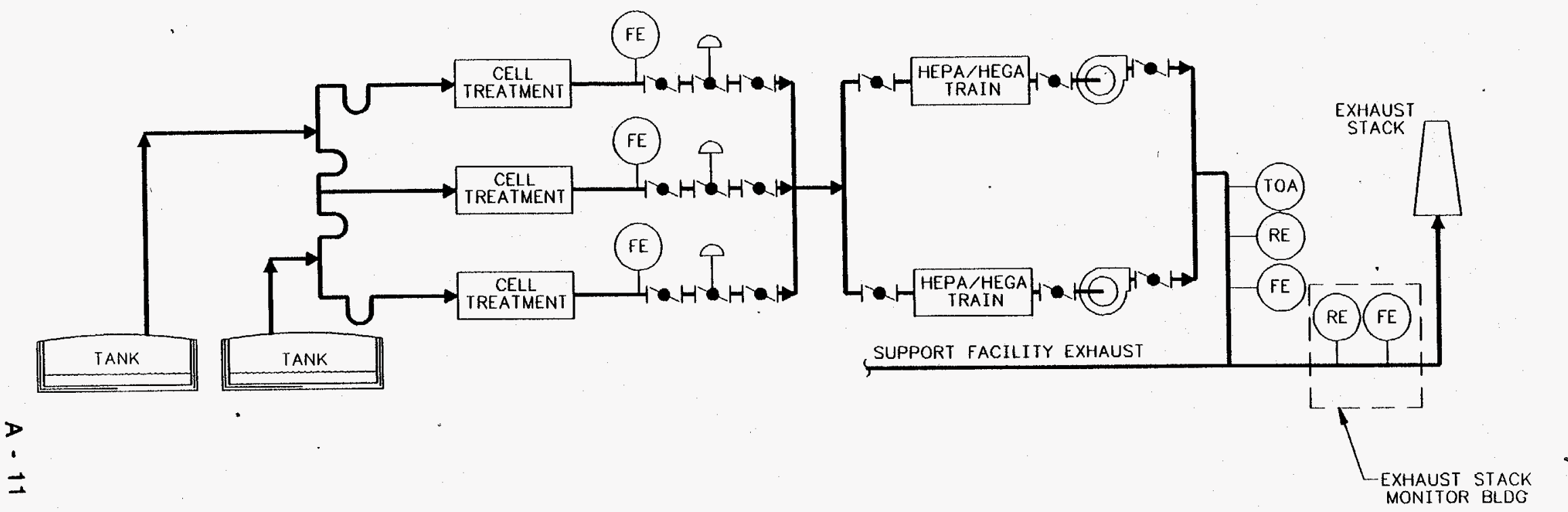

200 WEST PRIMARY VENT SYSTEM

\section{OPTION "BF"}

SAME AS OPIION "BB" WITH THE FOLLOWING:

ELIMINATES VALVES IN CELLS, PLACES VALVES

IN CONTACT MAINTENANCE AREA 
WHC-Sd-W236A-TI-009

Rev. 0

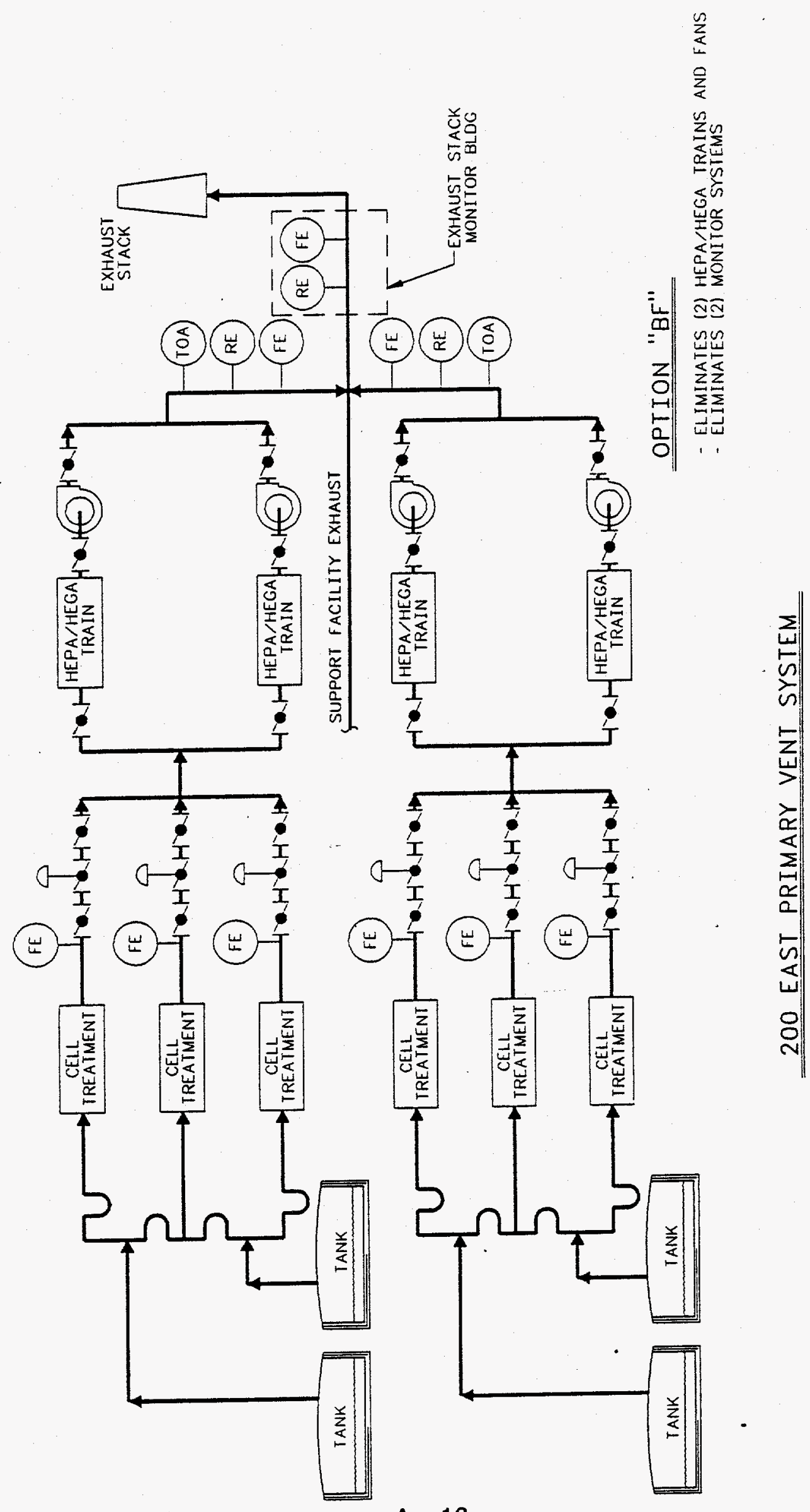

A -12 
WHC-SD-W236A-TI-009

Rev.0

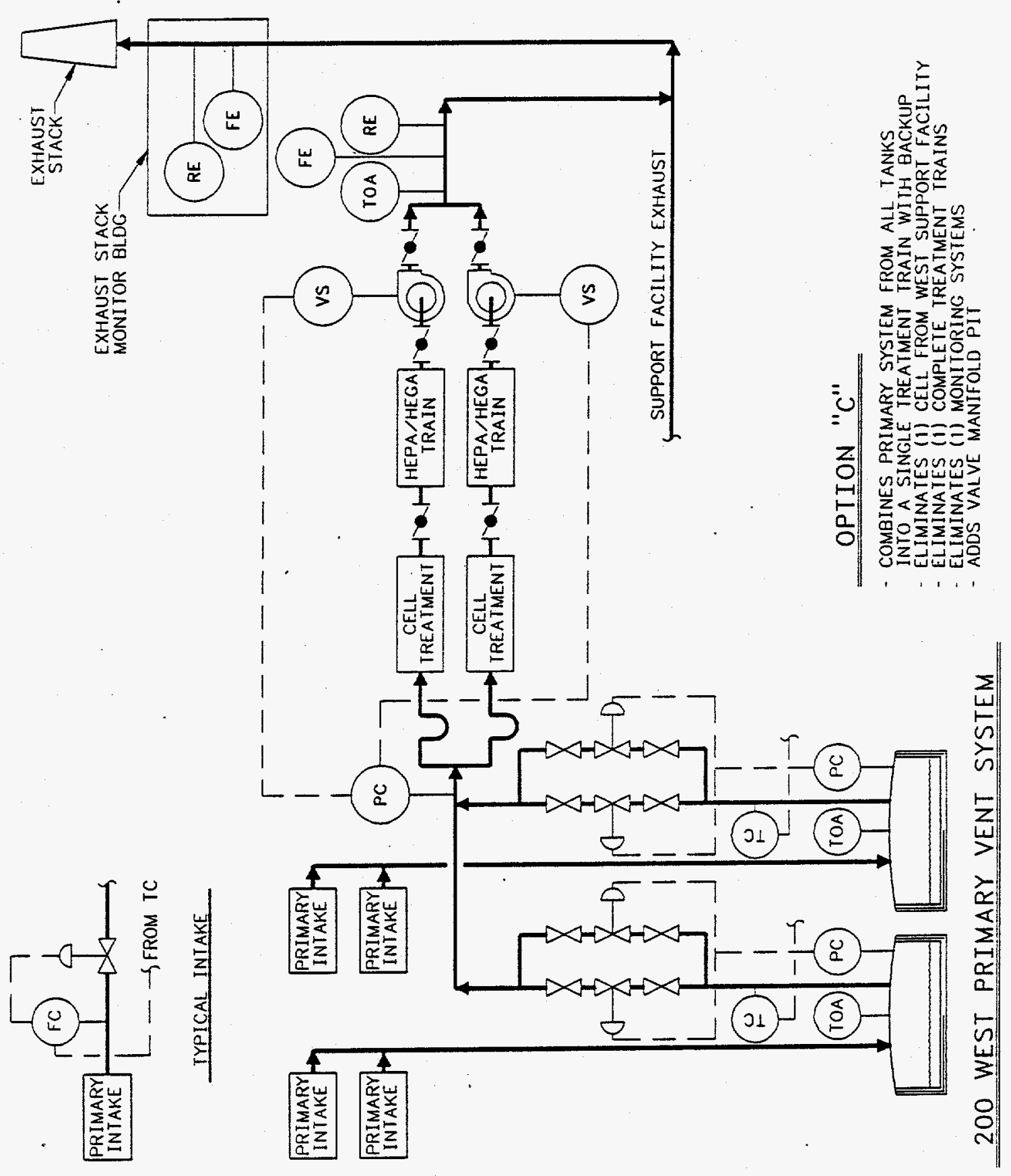


WHC-SD-W236A-TI-009

Rev. 0
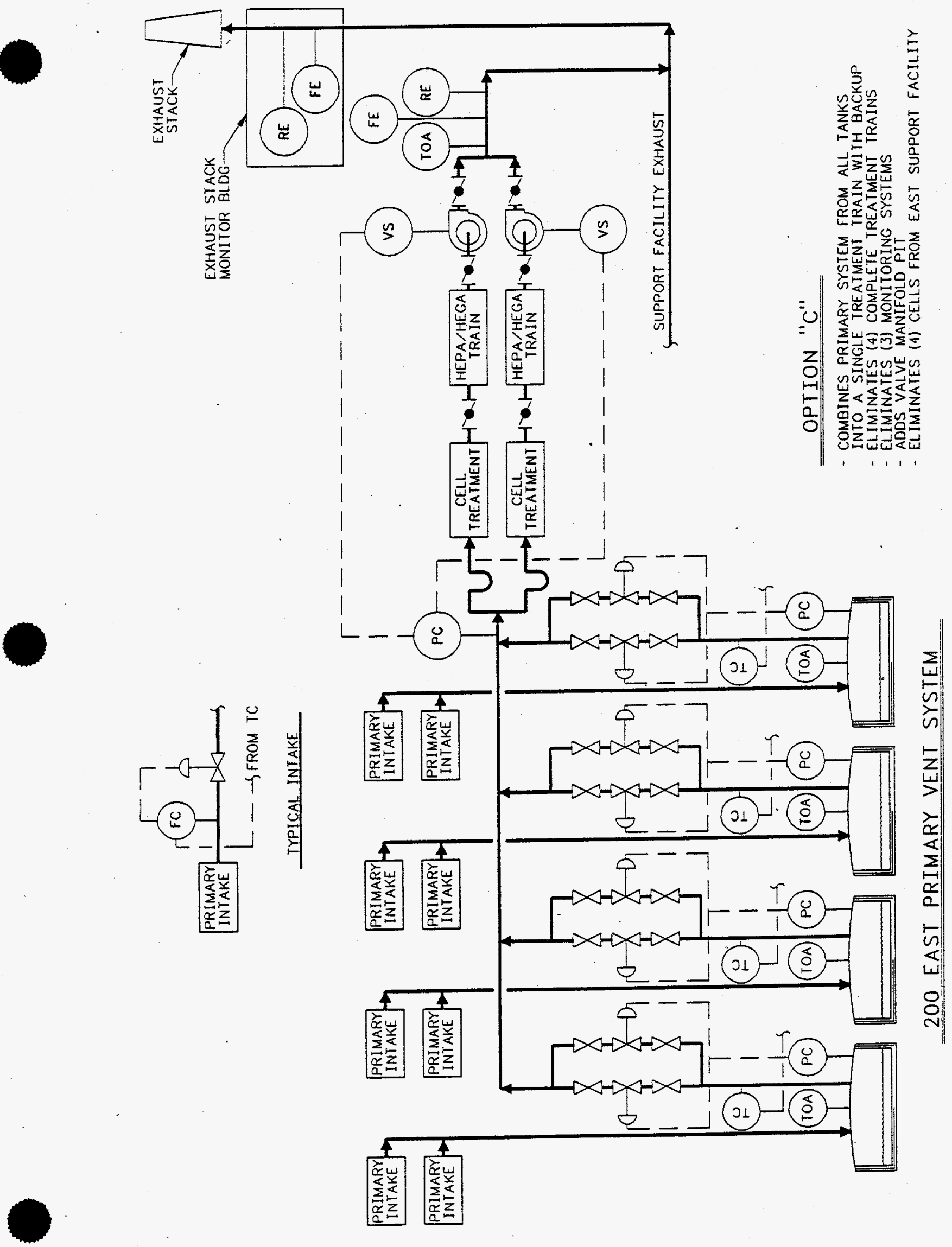
WHC-SD-W236A-TI-009

Rev.0

\section{Attachment B}

\section{Breakdown of Estimated Savings}




\begin{tabular}{|c|c|c|c|c|c|c|c|}
\hline WBS & WBS DESCRIPTION & EST: & $\begin{array}{l}\text { TOTAL EST } \\
\text { COST } \\
\text { (TITLE I CHK 2) }\end{array}$ & TOTAL ALTBF & $\begin{array}{l}\text { TOTALALT DF } \\
\text { EASTMEST }\end{array}$ & $\begin{array}{l}\text { DELTA COST } \\
\text { BETWEEN BF } \\
\text { AND DF }\end{array}$ & REMARKS \\
\hline 4323BO & Primary Exhaust System & CDR & 631,291 & 695,847 & 666,564 & $(29,284)$ & Duct \& Install Train Cost Only \\
\hline 4323KO & Exhaust Stack & CDR & $2,563,373$ & . $(730,798)$ & $(730,798)$ & 0 & Stack Change is Same Both Alternates \\
\hline 432480 & HVAC Bldg Instm/Tubing (Local) & TIP & $2,418,560$ & $(162,946)$ & $(217,294)$ & $(54,348)$ & Mechanical Train Instrumentation Costs \\
\hline 4329AO & Primary Exhaust Rad Monitors & TIP & $2,775,927$ & $(1,581,485)$ & $(1,909,769)$ & $(328,284)$ & $\begin{array}{l}\text { All Electrical Instrumentation (Including } \\
\text { Rad Monitor Installation) }\end{array}$ \\
\hline $4522 \mathrm{BO}$ & Primary Exhaust Air System & CDR & 627,941 & $(135,825)$ & $(234,634)$ & $(98,809)$ & Fan \& Filter Procurement Costs \\
\hline 452400 & Electrical Procurement & TIP2 & $13,066,412$ & $(1,498,120)$ & $(1,906,190)$ & $(408,070)$ & Radiation Monitor Procurement \\
\hline & Subtotal & & & $(3,413,326)$ & $(4,332,121)$ & $(918,795)$ & \\
\hline & Escalation & & & $(333,530)$ & $(420,117)$ & $(86,587)$ & \\
\hline & Contingency & & & $(766,340)$ & $(969,038)$ & $(202,697)$ & \\
\hline & TOTAL SAVINGS & & & $(4,513,197)$ & $(5,721,277)$ & $(1,208,080)$ & \\
\hline
\end{tabular}

